\title{
The Strengths and Weaknesses of Using Google Classroom for Blended Learning
}

\author{
Ni Luh Putu Sumartini ${ }^{1 *}$, Dewa Ayu Eka Agustina ${ }^{2 *}$, Luh Diah Surya Adnyani ${ }^{3 *}$ (D)
}

2,3 English Language Ganesha University of Education, Bali, Indonesia

\section{A R T I C L E I N F O}

Article history:

Received May 28, 2021

Revised May 29, 2021

Accepted July 20, 2021

Available online August 25, 2021

Kata Kunci:

Pembelajaran Online,

Pembelajaran Campuran, google classroom

Keywords:

Online Learning, Blended

Learning, Google Classroom

DOI:

http://dx.doi.org/10.23887/jpbi.v 9i2.34820

\begin{abstract}
A B S T R A K
Teknologi memegang peranan penting dalam perkembangan pendidikan di Indonesia. Guru harus menggunakan IT untuk meningkatkan motivasi belajar siswa. Blended learning merupakan salah satu cara yang harus digunakan guru untuk memfasilitasi interaksi pembelajaran yang menggabungkan metode pembelajaran konvensional dengan teknologi. Google Classroom merupakan salah satu aplikasi termudah yang dapat membantu guru dan siswa menghabiskan lebih banyak waktu untuk berdiskusi dalam pembelajaran online. Dalam pembelajaran online, penggunaan beberapa aplikasi dapat memberikan dampak baik positif maupun negatif selama proses berlangsung. Penelitian ini bertujuan untuk menganalisis. Kelebihan dan Kekurangan Menggunakan Google Classroom untuk Pembelajaran Campuran. Jenis penelitian ini yaitu kualitatif. Subjek penelitian ini berjumah 12 orang mahasiswa. Pengumpulan data dilakukan dengan observasi dan wawancara. Instrument yang digunakan untuk mengumpulkan data yaitu kuesioner. Teknik yang digunakan untuk menganalisis data yaitu analisis deskriptif kualitatif dan kuantitatif. Hasil penelitian yaitu 85\% siswa mengalami kesulitan saat melakukan komunikasi tertulis di kolom komentar. Selain itu, 5\% siswa menyatakan bahwa mudah untuk berbagi dan mendiskusikan ide selama interaksi online. Sebaliknya, 40\% siswa menyatakan bahwa Google Classroom mudah dioperasikan dan digunakan.
\end{abstract}

\section{A B S T R A C T}

Learning Technology plays a crucial role in the development of education in Indonesia. Teachers should use IT to increase students' learning motivation. Blended learning is one way teachers should facilitate learning interactions that combine conventional learning methods with technology. Google Classroom is one of the most accessible applications to help teachers and students need more time to study online learning. In online learning, several applications can have both positive and negative impacts during the process. This study aims to analyze. Advantages and Disadvantages of Google Classroom for Mixed Learning. This type of research is qualitative. The subjects of this study were 12 students. Data collection was done by observation and interviews. The instrument used to collect data is a questionnaire. The technique used to analyze the data is descriptive qualitative and quantitative analysis. The result of the research is that $85 \%$ of students have difficulty communicating in writing in the comments column. In addition, 5\% of students stated that it is easy to share and share ideas during online interactions. In contrast, $40 \%$ of students stated that Google Classroom was easy to operate and use.

This is an open access article under the CC BY-SA license. Copyright (C) 2021 by Author. Published by Universitas Pendidikan Ganesha.

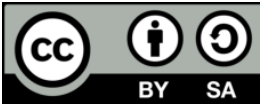

\section{INTRODUCTION}

Indonesians have been using modern gadgets for communication every day, including for educational purposes (Ompi et al., 2020; Pebriana, 2017). Teachers now are required to be able to use instructional and communicational technology to help students in the learning process (Jang et al., 2021; Summak et al., 2010). Teachers in Indonesia have been using ICT in their profession. Many schools have already used computers and mobile devices in the classroom to improve the students' academic performance (Alias \& Siraj, 2012; Goldschmidt, 2020). Using a computer for learning is one of the challenges in higher education. Blended learning is a model of learning that combines face-to-face instruction with instruction through the computer (Akyol \& Garrison, 2011; Bervell \& Arkorful, 2020). By using blended learning students can learn at any time at home, which can save their time. The students can submit assignments easily and quickly (Bock et al., 2018; Rahmat, 2020). Technology is one of the many devices used by managers in anticipating changes. Technology has been proven to enhance students' activities participation enthusiasm regarding the learning outcomes (Sahin \& Yilmaz, 2020; Yavuz et al., 2021). Students are the happiest and most active to join the online learning process compared to the traditional method that leads students to be passive. Moreover, students are considered to be more motivated to get involved when the teachers integrate the technological use while explaining the learning material (Burik, 
2021; Kaplan et al., 2021). Because of that phenomenon, students and teachers as the part of learning process realize the importance of educational technology.

In an online course, teachers use Google Classroom for online learning (Ali \& Maksum, 2020; Permata \& Bhakti, 2020). It was firstly published by Google Apps in 2004 which is specifically designed for educational purposes and promotes an interactive online learning environment (Al-Maroof \& Al-Emran, 2018). Google Classroom can help teachers spend more time do a discussion with their students online, the students can submit their assignments easily with Google Classroom and this application is free (Kurniawati et al., 2019; Wan Hassan et al., 2020). Google Classroom is one of the best applications for an e-learning platform. This application provides features to be used in online learning with the students. Google Classroom can help teachers save time and communicate with the students easily. It is available for the students to access with Google Apps for Education (Albashtawi \& Al Bataineh, 2020; Soni et al., 2018). Google Classroom is a tool that facilitates students' and teachers' collaboration; also, the teacher can make and distribute assignments for students in an online classroom for free" (Khalil, 2018; Setiawan \& Ari Oka, 2020). Google classroom is to offers a platform of blended learning in schools to simplify creating assignments and getting the grade out to students in a paperless way (Mahitsa \& Mahardini, 2020).

The basic principle of mixed learning is a situation that directly interacts with online writing learning interaction that maximizes their combination so that each ability is incorporated into a concrete learning experience for context and purposes (Kristanto et al., 2017; Sjukur, 2012). Even though higher education in Indonesia has already used the technology, there is a problem for the students (Alfi et al., 2016; Tambunan et al., 2020). Most Indonesian students are still confused about how to use the technology or application for blended learning correctly (Akyol \& Garrison, 2011; Siregar \& Manurung, 2020). This is caused by the fact that they cannot use the technology for learning. They only use it for chatting with their friends. In addition, it occurs because in high school their teachers did not teach them about how to use the technology or application in the learning process. Thus, when they are studying in their first year at college, they still face difficulties or are inconvenient when using a computer or internet in their learning process (Mawarni \& Muhtadi, 2017; Pangaribuan \& Saragih, 2014).

Those statements are supported by the research is stated that the availability of equipment and tools to operate the computer was running well (Azizah et al., 2017; Gozali, 2020). However, the problem occurred due to the connectivity (Widiyono, 2020; Windhiyana, 2020). Both the teacher and the students found that using Google Classroom could improve their reading comprehension and increase the improvement of learning objectives since they could easily search for some other resources while making some online learning interactions (Guswara, 2020; Santosa et al., 2020). Moreover, using Google Classroom enables them to access the class easily from everywhere at any time. Teacher-centered learning is an old learning style that is no longer suitable for the current generation, so it must be changed to a student-centered approach, especially for students with diverse abilities (Handayani et al., 2017; Seika Ayuni et al., 2017). Therefore, teachers must be able to use various technologies and design, compile, guide, and assess student projects through online media (Danniels et al., 2020; McGarr \& Gallchóir, 2021).

Previous research findings found that students could easily improve their skills and abilities during learning classes through Google Classroom because this application provided them with images, data, information, and several other materials completely (Permata \& Bhakti, 2020; Setyawan et al., 2020). The use of Google Classroom can increase the ability for students to adopt and adapt the improvement of technology to support their skills (Al-Maroof \& Al-Emran, 2018; Ali \& Maksum, 2020). It is satisfying the students during the learning process due to the useful utility tools provided by Google Classroom. However, Alim also found that in certain limitations, not all the students and teachers could find the easiness of using Google Classroom (Alimin \& Saad, 2019). By the limitation of ability, there were still some teachers who hardly applied the technology in their regular conventional class (Alimin \& Saad, 2019). These teachers could not operate technology so that the class interaction and material distribution could be delayed and run ineffectively. Moreover, in certain economical conditions, not all of the students were provided with good and enough quota accessibility so that some would be absent from the class from the start or even in the middle of the class. Some connection problems can also disturb the concentration of the class.

Therefore, this study aimed to identify and analyze the effectiveness of Google Classroom as Blend Learning Method to find specific strengths and weaknesses of this media to improve the quality of the online learning process in the future. The identification of strengths and weaknesses of this learning media can provide such specific information on both the negative and positive sides of online learning methods that can be managed using a correct solution. Each positivity and negativity have a different side that must be known to find the best choice to adapt to the situation. Indeed, this study tried to analyze in what way these strengths and weaknesses gave influences during online learning process through Google Classroom. 


\section{METHOD}

This study used a qualitative method. The data were collected by observation and interview. The interview was informal. The researcher did an informal interview. The researcher only asked open-ended questions and allowed the participants to answer the questions based on what they knew without pushing them. The researcher interviewed the participants at different times and places using the same questions. In addition, the researchers also observed and read several sources in addition to gathering information. In the observation, the researcher explored further the application and the use of the application.

The participants of this study were 12 fifth-semester students of the English Language Education Department of the Ganesha University of Education in Singaraja who were taking an e-learning course and making e-learning platforms. These participants were from the $5 \mathrm{G}$ class. There were three male students and nine female students. The researcher chose the twelve students because they were using Google Classroom for the e-learning platform. They had made an e-learning platform and used it. The researcher interviewed these participants in the classroom and via social media with the same questions. The questions were open-ended. The researcher observed Google Classroom obtain the real data.

The researcher used four steps to collect the data. The first step was observation to see how the participants used Google Classroom in their e-learning platform. The second step was an interview with a semistructured design. The third was open-ended questions, to check the participants' opinions about the strengths and weaknesses of Google Classroom based on the participants' experiences. The three instruments that the researcher used were intended to obtain the data from the participants based on their understanding and experiences in using Google Classroom. The analysis of all data was organized to obtain findings that were interpreted appropriately, starting with organizing the data and continued reading them to get a general understanding. The last step that had to be done was interpreting the data before the data were finally presented.

\section{RESULT AND DISCUSSION}

\section{Result}

This section provides the result of the questionnaires answered by the participants regarding their opinions about the strengths and weaknesses of using Google Classroom. The questionnaire had two items that had to be answered by the participants. The first research question is aimed to find the strengths of using Google Classroom. From all of the participants, some said that they liked to use Google Classroom as a tool in blended learning. Their reasons can be shown in the following table 1 .

Table 1. Student's Opinion about the Strength of Using Google Classroom

\begin{tabular}{|c|c|c|c|}
\hline \multirow[t]{2}{*}{ Students (N) } & \multicolumn{2}{|c|}{ Opinion } & \multirow[t]{2}{*}{ Explanation } \\
\hline & Strength & Weakness & \\
\hline 4 students & $\sqrt{ }$ & & $\begin{array}{l}\text { The students find it is easy to operate and use Google } \\
\text { Classroom }\end{array}$ \\
\hline 3 students & $\sqrt{ }$ & & Paperless \\
\hline 1 student & $\sqrt{ }$ & & Easy to shares and discuss new ideas effectively \\
\hline 2 students & $\sqrt{ }$ & & Can be accessed through any device from everywhere \\
\hline 2 students & $\sqrt{ }$ & & $\begin{array}{l}\text { Learning from outside school is more interactive and } \\
\text { less pressure }\end{array}$ \\
\hline 10 students & & $\sqrt{ }$ & $\begin{array}{l}\text { Complicated to rely on a friend's comment in the } \\
\text { comment section }\end{array}$ \\
\hline 2 students & & $\sqrt{ }$ & Teachers cannot attach document files \\
\hline
\end{tabular}

From Table 1, it can be seen that almost $85 \%$ of the students found it difficult when doing written communication in the comment section because Google Classroom did not provide this feature. Moreover, even though it is considered a strength, only $5 \%$ of the students stated that it is easy to share and discuss ideas during online interaction which means that most class members had no intention to this point, did not enjoy the class because it is just an online class, or hard to get good connectivity to join the discussion session. On the contrary, $40 \%$ of the students stated that Google Classroom is easy to be operated and used.

\section{Discussion}


Most of the participants told that the Google Classroom application is easy to use. Four students gave comments that Google Classroom is easy to use. This shows that Google Classroom is easy to use by students (AlMaroof \& Al-Emran, 2018; Kurniawati et al., 2019). Three students had comments that it is easy to submit an assignment with Google Classroom and there is no need to use paper when Google Classroom is used (Albashtawi \& Al Bataineh, 2020; Soni et al., 2018). Two students stated that Google Classroom can be accessed from all devices, even though the students do not have the application. One student commented that they can communicate and share ideas effectively with their friends and two students stated that the students can learn outside of the school when using Google Classroom. Moreover, the result shows that there are only two weaknesses of using the Google Classroom application. From the two weaknesses, the participants could solve that problem. 10 students gave their opinions that indicate that they cannot reply to their friends' statements. Two students said that a teacher in an e-learning platform cannot attach document files.

The result has shown that there are several strengths and weaknesses found in using Google Classroom. From Table 1, Google Classroom has more strengths than weaknesses. There are more strengths in using Google Classroom (Khalil, 2018; Setiawan \& Ari Oka, 2020). However, Google Classroom has weaknesses as a tool for blended learning. The participants knew that every application has weaknesses; they still used this application and found the solution for every weakness. The teacher and students were able to make better interactions with Google Classroom in online discussion (Mahitsa \& Mahardini, 2020; Subandi et al., 2018). The strengths of Google Classroom arouse the participants' interest to use it at school in the future where they had become teachers (Guswara, 2020; Haka et al., 2020). The weakness of Google Classroom for the teacher is that it cannot attach documents files. The solution to that problem is the teacher has to write the material that will be given to the students. One of the problems is that most of the students do not reply to their friends' comments, so when the student wants to comment on his or her friend's statement, the student will be confused, where they have to comment. The solution is the students have to pay attention to their friend's comments and to know for whom they give their comments. Therefore, the participants can use Google Classroom better (Daniati et al., 2020; Santosa et al., 2020).

From the findings, it can be seen that the difficulty of online learning to Google Classroom is experienced when the students want to comment on the uploaded material or discussion topics brought by their friends. It is in contrast to the statement from the students who also stated that Google Classroom mediated them easily and effectively to share their opinion. Because of that, due to analytical research, it is found that the contradictive statement derives from several limitation conditions of the class. (1) The discussion seems effective and easy because it refers to online interaction and meetings. There is no relation to the comment section material. It attaches to the virtual meeting done by the students and the teacher where in this section, whenever the students have questions or opinions, they are allowed to raise their hands using the reaction feature so that the teacher can notice them easily rather than when they are doing an offline class where they tend to feel shy and afraid to ask a question. (2) The feature of Google Classroom provides the students a way to open another platform so that they have enough space and time to find a source of information on the internet.

However, the statement about the difficulties to use the comment section refers to the attachment file feature provided by Google Classroom. In this section, the comment section is restricted due to several reasons such as (1) to limit the unnecessary discussion between students in material attachment and (2) to avoid cheating on others' assignments. In this feature, students can comment on the other works or the attachment file uploaded by the teacher when they have already uploaded their assignment (Alimin \& Saad, 2019; Putri, 2020). Moreover, the comment section is opened only between the specific students and the teacher because the format of Google Classroom itself is like personal learning media, so the shape of the comment section is different from the chat on other social media. Based on the analysis, the strength of using Google Classroom can be improved more to give students basic ability in adopting technological changes during online learning classes while the weakness can be prevented by following the regulation of online learning classes thoroughly (Mansyur, 2020; Yunitasari \& Hanifah, 2020).

\section{CONCLUSION}

Blended learning has to be improved in Indonesian schools. The teachers must learn about how to use technology in teaching in the classroom. The teachers have to combine face-to-face instruction with instruction through the computer. It can help the students prepare for the twenty-first century in which the learning process will be using technology. The application or tool that the teacher can use to support their blended learning is Google Classroom. There are more strengths that Google Classroom has than its weaknesses. One of the strengths of Google Classroom is it is easy to use because it can be accessed from all devices. The researcher got a limited number of answers from the participants because they had the same opinions about the strengths and weaknesses of using Google Classroom. 


\section{REFERENCES}

Akyol, Z., \& Garrison, D. R. (2011). Understanding cognitive presence in an online and blended community of inquiry: Assessing outcomes and processes for deep approaches to learning. British Journal of Educational Technology, 42(2), 233-250. https://doi.org/10.1111/j.1467-8535.2009.01029.x

Al-Maroof, R. A. S., \& Al-Emran, M. (2018). Students Acceptance of Google Classroom: An Exploratory Study using PLS-SEM Approach. International Journal of Emerging Technologies in Learning (IJET), 13(06), 112-123. https://doi.org/10.3991/ijet.v13i06.8275

Albashtawi, A. H., \& Al Bataineh, K. B. (2020). The effectiveness of google classroom among EFL students in Jordan: An innovative teaching and learning online platform. International Journal of Emerging Technologies in Learning, 15(11), 78-88. https://doi.org/10.3991/IJET.V15I11.12865

Alfi, C., Sumarmi, S., \& Amirudin, A. (2016). Pengaruh Pembelajaran Geografi Berbasis Masalah Dengan Blended Learning Terhadap Kemampuan Berpikir Kritis Siswa SMA. Jurnal Pendidikan - Teori, Penelitian, Dan Pengembangan, 4(1). https://doi.org/10.17977/jp.v1i4.6203

Ali, M. K., \& Maksum, H. (2020). Utilization of E-Learning-Based ICT Learning Using the Google Classroom Application During the COVID-19 Pandemic. Journal of Education Research and Evaluation, 4(4), 373. https://doi.org/10.23887/jere.v4i4.29181

Alias, N., \& Siraj, S. (2012). Effectiveness of Isman Instructional Design Model in Developing Physics Module based on Learning Style and Appropriate Technology. Procedia - Social and Behavioral Sciences, 64. https://doi.org/10.1016/j.sbspro.2012.11.002

Alimin, F. G., \& Saad, M. S. M. (2019). The Effectiveness of Google Classroom as an Instructional Media: A Case of State Islamic Institute of Kendari, Indonesia. Journal of Humanities and Social Sciences, 7(2). https://doi.org/10/18510/hssr.2019.7227

Azizah, S., Khuzaemah, E., \& Rosdiana, I. (2017). Penggunaan Media Internet eXe-Learning Berbasis Masalah pada Materi Perubahan Lingkungan untuk Meningkatkan Hasil Belajar Siswa dalam kehidupan sehariharinya dan juga psikomotor ( keterampilan ) siswa . Proses belajar dapat materi dan bahan belajar yang. Scientiae Educatia: Jurnal Pendidikan Sains, 2005, 197-213. https://doi.org/10.24235/sc.educatia.v6i2.1957

Bervell, B., \& Arkorful, V. (2020). LMS-enabled blended learning utilization in distance tertiary education: establishing the relationships among facilitating conditions, voluntariness of use and use behaviour. International Journal of Educational Technology in Higher Education, 17(1), 6. https://doi.org/10.1186/s41239-020-0183-9

Bock, A., Modabber, A., Kniha, K., Lemos, M., Rafai, N., \& Hölzle, F. (2018). Blended learning modules for lectures on oral and maxillofacial surgery. British Journal of Oral and Maxillofacial Surgery, 56(10), 956961. https://doi.org/10.1016/j.bjoms.2018.10.281

Burik, A. (2021). Using Technology to Help Students Set, Achieve, and Publicize Goals. Adult Literacy Education: The International Journal of Literacy, Language, and Numeracy, 3(1), 83-89. https://doi.org/10.35847/aburik.3.1.83

Daniati, D., Ismanto, B., \& Luhsasi, D. I. (2020). Upaya Peningkatan Motivasi dan Hasil Belajar Mahasiswa dengan Penerapan Model Pembelajaran E-Learning Berbasis Google Classroom pada Masa Pandemi Covid19. Jurnal Kependidikan: Jurnal Hasil Penelitian Dan Kajian Kepustakaan Di Bidang Pendidikan, Pengajaran Dan Pembelajaran, 6(3), 601. https://doi.org/10.33394/jk.v6i3.2642

Danniels, E., Pyle, A., \& DeLuca, C. (2020). The role of technology in supporting classroom assessment in playbased kindergarten. Teaching and Teacher Education, 88. https://doi.org/10.1016/j.tate.2019.102966

Goldschmidt, K. (2020). The COVID-19 Pandemic: Technology use to Support the Wellbeing of Children. Journal of Pediatric Nursing, 53, 88-90. https://doi.org/10.1016/j.pedn.2020.04.013

Gozali, A. (2020). Bimbingan dan konseling berbasis teknologi informasi pada masa PSBB ( Pembatasan Sosial Berskala Besar ). Jurnal Bimbingan Konseling Pendidikan Islam Coution: Journal of Counseling and Education Layanan, 1(2), 36-49. https://doi.org/10.47453/coution.v1i2.117

Guswara, A. M. (2020). The Contribution of Google Classroom Application and Motivation to The Learning Outcomes of Web Programming. Educational Technology, 4(4), 1-9. https://doi.org/10.23887/jet.v4i4.29896

Haka, N. B., Anggita, L., Anggoro, B. S., \& Hamid, A. (2020). Pengaruh Blended Learning Berbantukan Google Classroom Terhadap Keterampilan Berpikir Kreatif Dan Kemandirian Belajar Peserta Didik. Edu Sains Jurnal Pendidikan Sains \& Matematika. https://doi.org/10.23971/eds.v8i1.1806

Handayani, N. M. D., Ganing, N. N., \& Suniasih, N. W. (2017). Model Pembelajaran Picture and Picture Berbantuan Media Audio-Visual Terhadap Pengetahuan IPA. Journal of Education Technology, 1(3), 176. https://doi.org/10.23887/jet.v1i3.12502

Jang, M., Aavakare, M., Nikou, S., \& Kim, S. (2021). The impact of literacy on intention to use digital technology 
for learning: A comparative study of Korea and Finland. Telecommunications Policy, 45(7). https://doi.org/10.1016/j.telpol.2021.102154

Kaplan, L. R., Farooque, M., Sarewitz, D., \& Tomblin, D. (2021). Designing Participatory Technology Assessments: A Reflexive Method for Advancing the Public Role in Science Policy Decision-making. Technological Forecasting and Social Change, 171. https://doi.org/10.1016/j.techfore.2021.120974

Khalil, Z. M. (2018). EFL Students' Perceptions towards Using Google Docs and Google Classroom as Online Collaborative Tools in Learning Grammar. Applied Linguistics Research Journal, 2(2), 33-48. https://doi.org/10.14744/alrj.2018.47955

Kristanto, A., Mustaji, \& Mariono, A. (2017). The development of instructional materials e-learning based on blended learning. Journal International Education Studies, 10(7), 10-17. https://doi.org/10.5539/ies.v10n7p10

Kurniawati, M., Santanapurba, H., \& Kusumawati, E. (2019). Penerapan Blended Learning Menggunakan Model Flipped Classroom Berbantuan Google Classroom Dalam Pembelajaran Matematika Smp. EDU-MAT: Jurnal Pendidikan Matematika, 7(1), 8-19. https://doi.org/10.20527/edumat.v7i1.6827

Mahitsa, M., \& Mahardini, A. (2020). Analisis Situasi Penggunaan Google Classroom pada Pembelajaran Daring Fisika. Jurnal Pendidikan FIsika, VIII(2), 215-224. https://doi.org/10.24127/jpf.v8i2.3102

Mansyur, A. R. (2020). Dampak COVID-19 Terhadap Dinamika Pembelajaran Di Indonesia. Education and Learning Journal, 1(2), 113. https://doi.org/10.33096/eljour.v1i2.55

Mawarni, \& Muhtadi. (2017). Pengembangan Buku Digital Interaktif Mata kuliah Pengembangan Multimedia Pembelajaran Interaktif Untuk Mahasiswa Teknologi Pendidikan. Jurnal Inovasi Teknologi Pendidikan, 4(1). https://doi.org/10.21831/jitp.v4i1.10114

McGarr, O., \& Gallchóir, C. Ó. (2021). Examining supervising field instructors' reporting and assessment of technology use by pre-service teachers on school placement. Computers \& Education, 146. https://doi.org/10.1016/j.compedu.2019.103753

Ompi, Sompie, \& Sugiarso. (2020). Video animasi interaktif 3d dampak penggunaan gadget pada anak sekolah dasar tingkat awal. Jurnal Teknik Elektro Dan Komputer, 9(2). https://doi.org/10.35793/jtek.9.2.2020.29717

Pangaribuan, \& Saragih. (2014). Pengembangan Multimedia Pembelajaran Interaktif Mata Kuliah Seni Lukis I Jurusan Seni Rupa. Jurnal Teknologi Informasi \& Komunikasi Dalam Pendidikan, 1(1), 75-86. https://doi.org/10.24114/jtikp.v1i1.1871

Pebriana, P. H. (2017). Analisis Kemampuan Berbahasa dan Penanaman Moral pada Anak Usia Dini melalui Metode Mendongeng. Jurnal Obsesi: Journal of Early Childhood Education, 1(2). https://doi.org/10.31004/obsesi.v1i2.34

Permata, A., \& Bhakti, Y. B. (2020). Keefektifan Virtual Class dengan Google Classroom dalam Pembelajaran Fisika Dimasa Pandemi Covid-19. JIPFRI (Jurnal Inovasi Pendidikan Fisika Dan Riset Ilmiah), 4(1), 2733. https://doi.org/10.30599/jipfri.v4i1.669

Putri, V. D. (2020). Layanan Bimbingan dan Konseling Daring Selama Masa Pandemi COVID-19. Jurnal Bimbingan Konseling Pendidikan Islam, 1(2), 7-16. https://doi.org/10.47453/coution.v1i2.95

Rahmat, I. (2020). Implementasi Andragogi Platform E-learning pada Blended Learning di Universitas Negeri Padang. Journal of Education Technology, 4(2), 133. https://doi.org/10.23887/jet.v4i2.24817

Sahin, D., \& Yilmaz, R. M. (2020). The effect of Augmented Reality Technology on middle school students' achievements and attitudes towards science education. Computers \& Education, 144. https://doi.org/10.1016/j.compedu.2019.103710

Santosa, F. H., Negara, H. R. P., \& Samsul Bahri. (2020). Efektivitas Pembelajaran Google Classroom Terhadap Kemampuan Penalaran Matematis Siswa. Jurnal Pemikiran Dan Penelitian Pendidikan Matematika (JP3M), 3(1), 62-70. https://doi.org/10.36765/jp3m.v3i1.254

Seika Ayuni, I. G. a. P. A., Kusmariyatni, N., \& Japa, I. G. N. (2017). Pengaruh Model Pembelajaran Talking Stick Berbantuan Media Question Box Terhadap Hasil Belajar Ipa Kelas V. Journal of Education Technology, 1(3), 183. https://doi.org/10.23887/jet.v1i3.12503

Setiawan, I. M. D., \& Ari Oka, I. D. G. (2020). The Use of Audio-Visual Assisted Google Classroom for Mathematics Course. Journal of Education Technology, 4(3), 244. https://doi.org/10.23887/jet.v4i3.28529

Setyawan, A., Aznam, N., \& Citrawati, T. (2020). Effects of the Google Meet Assisted Method of Learning on Building Student Knowledge and Learning Outcomes. Universal Journal of Educational Research, 8(9), 3924-3936. https://doi.org/10.13189/ujer.2020.080917

Siregar, \& Manurung. (2020). Pengaruh Blended Learning terhadap Kreativitas Mahasiswa Calon Guru di Universitas Negeri Medan. Edumatika: Jurnal Riset Pendidikan Matematika, 3(1). https://doi.org/10.32939/ejrpm.v3i1.485

Sjukur, S. (2012). Pengaruh Blended Learning Terhadap Motivasi Belajar Dan Hasil Belajar Tingkat SMK. Jurnal Pendidikan Vokasi, 2(3), 368-378. https://doi.org/10.21831/jpv.v2i3.1043 
Soni, Hafid, Hayami, Fatma, Wenando, Amien, Fuad, Unik, \& Mukhtar. (2018). Optimalisasi Penggunaan Google Classroom, E-Learning \& Blended Learning sebagai Media Pembelajaran Bagi Guru dan Siswa di SMK Negeri 1 Bangkinang. Jurnal Pengabdian Untukmu Negeri, 21. https://doi.org/10.37859/jpumri.v2i1.361

Subandi, S., Choirudin, C., Mahmudi, M., Nizaruddin, N., Hermanita, H., \& Hermanita, H. (2018). Building interactive communication with Google Classroom. International Journal of Engineering \& Technology, 7(2.13), 460-463. https://www.sciencepubco.com/index.php/ijet/article/view/18141/8144

Summak, M. S., Bağlıbel, M., \& Samancıŏglu, M. (2010). Technology readiness of primary school teachers: A case study in Turkey. Procedia - Social and Behavioral Sciences, 2(2), 2671-2675. https://doi.org/10.1016/j.sbspro.2010.03.393

Tambunan, L. R., Siregar, N. A. R., \& Susanti, S. (2020). Implementasi E-book Berbasis Smartphone pada Materi Polinomial di Kelas XI SMA Negeri 4 Tanjungpinang. Jurnal Anugerah. https://doi.org/10.31629/anugerah.v2i2.2521

Wan Hassan, W. A. ., Ariffin, A., Ahmad, F., Sharber, S. N. ., Azizi, N., \& Zulkiflee, S. . (2020). COVID-19 Pandemic : Langkawi Vocational College Student Challenge in Using Google Classroom for Teaching and Learning ( T \& L ). International Journal of Advanced Trends in Computer Science and Engineering, 9(3), 3299-3307. https://doi.org/10.30534/ijatcse/2020/127932020

Widiyono, A. (2020). Efektifitas Perkuliahan Daring (Online) pada Mahasiswa PGSD di Saat Pandemi Covid 19. Jurnal Pendidikan, 8(2), 169-177. https://doi.org/10.36232/pendidikan.v8i2.458

Windhiyana, E. (2020). Dampak Covid-19 Terhadap Kegiatan Pembelajaran Online Di Perguruan Tinggi Kristen Di Indonesia. Perspektif Ilmu Pendidikan, 34(1), 1-8. https://doi.org/10.21009/pip.341.1

Yavuz, M., Çorbacıoğlu, E., Başoğlu, A. N., Daim, T. U., \& Shaygan, A. (2021). Augmented reality technology adoption: Case of a mobile application in Turkey. Technology in Society, 66. https://doi.org/10.1016/j.techsoc.2021.101598

Yunitasari, R., \& Hanifah, U. (2020). Pengaruh Pembelajaran Daring terhadap Minat Belajar Siswa pada Masa COVID 19. Edukatif: Jurnal Ilmu Pendidikan, 2(3), 232-243. https://doi.org/10.31004/edukatif.v2i3.142 